\title{
HUBUNGAN POLA ASUH KELUARGA, MEDIA MASSA DAN PENGARUH TEMAN SEBAYA TERHADAP PENGETAHUAN PERILAKU SEKSUAL PADA REMAJA
}

\begin{abstract}
Sudibyo*, Endang Suartini *
Abstrak

Perilaku remaja yang melakukan seks pranikah berhasil dibuktikan olehbeberapa penelitian diantaranya hasil survei di 12 kota dan di kota Medan diketahui bahwa sekitar 5,5\% - 11\% remaja di Indonesia telah melakukan hubungan seksual sebelum usia 19 tahun sedangkan yang melakukan hubungan seksual pada usia 19-24 tahun sekitar 14,7\%-30\%.(Ellis,2002).Penelitian ini bertujuan untuk mengetahui hubungan pola asuh keluarga terhadap pengetahuan perilaku seksual pada remaja, untuk mengetahui hubungan media massa terhadap pengetahuan perilaku seksual pada remaja, untuk mengetahui hubungan antara pengaruh teman sebaya terhadap pengetahuan perilaku seksual pada remaja. Penelitaian ini menggunakan metode survei analitik dengan pendekatan cross sectional. Dan teknik analisis menggunakan chi-square. Hasil penelitian di dapatkan $\mathrm{P}=0,57$ (P>0.05) dan nilai OR 0,771 (95\% CI:0,283-2,099 maka di simpulkan bahwa hubungan pola asuh dengan perilaku seksual tidak ada hubungan dengan perilaku seksual remaja.P = 0,426 (P>0.05) dan nilai OR 1,800 (95\% CI:0,391-8,292 maka di simpulkan bahwa hubungan pengaruh teman sebaya tidak ada hubungan dengan perilaku seksual remaja.P 0,040dan nilai OR 5,000 (95\% CI:1,08523,034). Dengan demikian secara statistik pada tingkat kepercayaan $5 \%$ menunjukan ada hubungan yang bermakna antara media masa dengan pengetahuan perilaku seksual remaja, hubungan antara media massa, dengan pengetahuan perilaku seksual remaja, media massa disini lebih bersifat media massa porno. Sejalan dengan perkembangan sistem informasi banyak pihak-pihak tertentu yang sering menyalah gunakan media informasi demi keuntungan sendiri yang merugikan banyak anak -anak remaja
\end{abstract}

\section{Kata kunci: Polaasuh keluarga, Media Massa, Teman sebaya, Prilaku seksual Remaja}

*Poltekkes Kemenkes Banten 


\begin{abstract}
Absrack
Conduct pre teen sex marriage is proved by a number of research works of which surveys in 12 cities and in the field of mind that around $5.5 \%-11 \%$ of teenagers in Indonesia have had sexual intercourse before the age of 19 when the sexual intercourse at the age of 19-24 year around 14.7\% -30\%. (Ellis, 2002). This study aims to determine the relationship between patterns of family foster knowledge on adolescent sexual behavior, to determine the relationship between the mass media on knowledge about sexual behavior in adolescents, to determine the relationship between the influence of peers on knowledge about sexual behavior in adolescents. Penelitaian uses analytical survey method with cross-sectional approach. And techniques using a chi-square analysis. Get the research results at $P=0.57(P>0.05)$ and the OR 0.771 (95\% CI :0,283-2, 099 then conclude that the relationships fostered with sexual behavior patterns are not related to adolescent sexual behavior. $P=0.426(P>0.05)$ and the OR $1.800(95 \% C I$ $: 0,391-8,292$ then conclude that peers influence relations are not related to adolescent sexual behavior. P value of 0.040 and OR 5.000 (95\% CI: 1.085 to 23.034). thus statistically at 5\% confidence level showed no meaningful relationship between the mass media with sexual behavior remaja.Disarankan knowledge should be able to select and isolate youth media outlet and run a good time and a bad time media. Till teenagers do not do things that deviate from norms in place, and Parents should be able to more actively seek contact with her especially during adolescence, because environmental influences are very significant effect on the behavior of adolescents.
\end{abstract}

Keywords:

Patterns of family foster care, Mass Media, The Influence of peers, and knowledge of sexual behavior in teens 


\section{Pendahuluan}

Berdasarkan data dari Biro PusatStatistik (BPS) tahun 2000 menunjukkanbahwajumlahremajausia 10 24 tahunmencapai 60.901 .709 atau $30 \%$ darijumlahpenduduk Indonesia yang berjumlah 201.241.999 jiwa. Dari jumlahremaja yang cukup besar saat ini dan pengaruh dari perkembangan informasi yang sangat pesat maka sangat memungkinkan remaja untuk melakukan perilaku seksual yang tidak sehat seperti hubungan seksual pranikah, peningkatan kasus aborsi dan terjangkitnya HIV/AIDS.Perilaku remaja yang melakukan seks pranikah berhasil dibuktikan oleh beberapa penelitian diantaranya hasil survei di 12 kota, dan di kota Medan diketahui bahwa sekitar 5,5\% $11 \%$ remaja di Indonesia telah melakukan hubungan seksual sebelum usia 19 tahunsedangkan yang melakukan hubungan seksual pada usia 19-24 tahun sekitar 14,7\%-30\%.(Ellis,2002).

Berdasarkan hasil penelitian Zondervan, mahasiswa Belanda tahun 1997 menunjukkan bahwa di Yogyakarta terdapat $60 \%$ remaja (Bernaz, 2000). Penelitian sahabat remaja tentang perilaku seksual di empat kota menunjukkan bahwa 3,65\% remaja di kota Medan, 8,5\% remaja di Yogyakarta, 3,4 \% remaja di kota Surabaya dan $31 \%$ di kota Kupang telah terlibat hubungan seksual secara aktif. (Tito,2001). Lingkungan keluarga adalah lingkungan pertama yang berpengaruh terhadap perkembangan anak, kesehatan fisik, kesehatan mental, dan spiritual yang akan diwujudkan dalam tingkah laku. Pola hidup keluarga, termasuk pola asuh orang tua dapat dipakai sebagai factor untuk memprediksi penyebab perilaku menyimpang bagi kesehatan remaja( Hadi, 2008).

Berdasarkan data di atas bahwa media massa, dan pengaruh teman sebaya dapat mempengaruhi perilaku seksual remaja, ini dapat pula dilihat bagaimana pola asuh orang tua.sehingga peneliti tertarik untuk meneliti Hubungan pola asuh orang tua, media massa dan pengaruh teman sebaya terhadap perilaku seksual pada remaja

\section{Metode Penelitian}

Penelitian ini menggunakan desain penelitian kuasi-eksperimen, dengan menggunakan Penelitian ini menggunakan metode survei analitik dengan pendekatan cross sectional.

Penentuan besar sampel menggunakan rumusCara pengambilan sampel dilakukan dengan random sampling yaitu secara acak 
sederhana.Sampel dalam penelitian ini berjumlah 80 siswa.

Alat yang digunakan sebagai pengumpulan data dalam peneitian ini berupa quasioner. Pengumpulan data dalam penelitian ini, data primer diambil dengan cara angket kepada responden dengan menggunakan kuesioner. Prosedur pengumpulan data adalah Responden adalah siswa SMK kesehatan dan SMA di kota tangerang. Pengumpulan data dilakukan dengan cara random sampling, dibantu guru $\mathrm{BP}$

Analisis data dalam penelitian ini diolah dengan program statistik. Analisis dilakukan secara univariat, bivariat dan multivariat. Analisis bivariat bertujuan untuk melihat hubungan Pola asuh keluarga, media massa dan pengaruh teman sebaya terhadap perilaku seksual pada remaja dengan menggunakan uji chi-square pada program SPSS.

HASIL

Tabel 1

DistribusiFrekwensiPolaAsuh Orang TuaPadaRemajaSMAN 7 dan SMK Kesehatan 21

\begin{tabular}{|c|c|c|c|}
\hline & Katagori & Jumlah & $\begin{array}{c}\text { Prosentase } \\
(\%)\end{array}$ \\
\hline Otoriter & & 10 & 12,5 \\
\hline Permisif & & 70 & 87,5 \\
\hline
\end{tabular}

\begin{tabular}{ll}
\hline 80 & 100 \\
\hline
\end{tabular}

Dari tabelterlihatbahwapolaasuh orang otoritersebanyak 10 orang $(12,5 \%)$ danpolaasuh orang tua yang permisifsebanyak 70 orang $(87,5 \%)$

Tabel 2

DistribusiFrekwensiPengaruhTemanSebaya PadaAnakRemajaSMAN 7 dan SMK Kesehatan 21

PolaAsuhKeluarga Jumlah Prosentase (\%)

\begin{tabular}{lcc}
\hline TidakTerpengaruh & 59 & 73,8 \\
\hline Terpengaruh & 21 & 26,2 \\
\hline & 80 & 100 \\
\hline
\end{tabular}

Dari table terlihat bahwa sebagian besar remaja tidak terpenngaruh oleh teman sebaya sebanyak 59 anak $73,8 \%$ dan ter pengaruh sebanyak 21 anak 26,2\%.

Tabel 3

DistribusiFrekwensiPenggunaan Media MasaSMAN 7 dan SMK Kesehatan 21 Katagori Jumlah Prosentase

\begin{tabular}{lcc}
\hline $\begin{array}{l}\text { TidakMenggunakan } \\
\text { Media Porno }\end{array}$ & 62 & 77,5 \\
\hline $\begin{array}{l}\text { Menggunakan } \\
\text { Media Porno }\end{array}$ & 18 & 22,5 \\
\hline & 80 & 100 \\
\hline
\end{tabular}


Dari tabel diatas remaja yang tidak menggunakan media porno sebanyak 62 anak $77,5 \%$ dan 18 anak $22,5 \%$ menggunakan media porno.

Tabel 4

Distribusi Frekwensi Perilaku Seksual Pada Remaja diSMAN 7 Dan Smk Kesehatan 21

\begin{tabular}{lcc}
\hline Katagori & Jumlah & $\begin{array}{c}\text { Prosentase } \\
(\%)\end{array}$ \\
\hline Baik & 72 & 90,0 \\
\hline TidakBaik & 8 & 10,0 \\
\hline Memukul & 80 & 100 \\
\hline
\end{tabular}

Dari tabel diatas sebagian perilaku sek yang baik sebanyak 72 anak 90\%, dan perilaku sek yang tidak baik sebanyak 8 anak $10 \%$.

Tabel 5

Distribusi Frekwensi Pola Asuh Dengan Pengetahuan Perilaku Seksual Remaja Di SMAN 7 Dan Smk Kesehatan 21

\begin{tabular}{|c|c|c|c|c|c|c|c|c|}
\hline \multirow{3}{*}{$\begin{array}{c}\text { Pola } \\
\text { Asuh } \\
\text { Keluarga }\end{array}$} & & nget & uar & erila & seks & & \multirow{3}{*}{$\begin{array}{l}\text { Nilai } \\
\text { P }\end{array}$} & \multirow{3}{*}{$\begin{array}{l}\text { OR } \\
95 \% \mathrm{CI}\end{array}$} \\
\hline & \multicolumn{2}{|c|}{ Baik } & \multicolumn{2}{|c|}{ T.Baik } & \multicolumn{2}{|c|}{ Total } & & \\
\hline & $\mathrm{n}$ & $\%$ & $\mathrm{n}$ & $\%$ & $\mathrm{n}$ & $\%$ & & \\
\hline Otoriter & 7 & 70 & 3 & 30 & 10 & 100 & \multirow{3}{*}{0,57} & \multirow{3}{*}{$\begin{array}{l}0,179 \\
(0,35- \\
0,916)\end{array}$} \\
\hline Permisif & 65 & $\begin{array}{l}92, \\
9\end{array}$ & 5 & 7,1 & 70 & 100 & & \\
\hline Jumlah & 72 & 90 & 8 & 10 & 80 & 100 & & \\
\hline
\end{tabular}

Dari 80 orang remaja dengan pola asuh yang berbeda didapatkan hasil pola permisif adalah pola yang mendominasi dalam pola asuh yang di berikan kepada remaja dengan jumlah 70 anak dimana 65 anak 92,9\% adalah berperilaku seksual yang baik dan 5 anak $7,1 \%$ berperilaku yang tidak baik. Sedangkan pola asuh orang tua yang otoriter sebanyak 10 anak. Dimana 7 anak 70,3 anak berperilakku seksual baik dan 3 anak $30 \%$ berperilaku tidak baik. Berdasarkan uji hubungan dengan menggunakan Chi- Squere didapatkan nilai $\mathrm{P}=0,57(\mathrm{P}>0.05)$ dan nilai $\mathrm{OR} 0,179(95 \%$ CI:0,35-2,916) maka di simpulkan bahwa hubungan pola asuh dengan perilaku seksual tidak ada hubungan dengan perilaku seksual remaja. 
Tabel 6

Distribusi Frekwensi Pengaruh Teman

Sebaya Dengan Perilaku Seksual Remaja di SMAN 7 dan SMK Kesehatan 21

\begin{tabular}{|c|c|c|c|c|c|c|c|c|}
\hline \multirow{3}{*}{$\begin{array}{l}\text { Temen } \\
\text { Sebaya }\end{array}$} & \multicolumn{6}{|c|}{ Tindakan perilaku seksual } & \multirow{3}{*}{ Nilai P } & \multirow{3}{*}{$\begin{array}{l}\text { OR } \\
95 \% \mathrm{CI}\end{array}$} \\
\hline & \multicolumn{2}{|r|}{ Baik } & \multicolumn{2}{|c|}{ T.Baik } & \multicolumn{2}{|c|}{ Total } & & \\
\hline & $\mathrm{n}$ & $\%$ & $\mathrm{n}$ & $\%$ & $\mathrm{~N}$ & $\%$ & & \\
\hline $\begin{array}{c}\text { Tidak } \\
\text { Terpeng } \\
\text { aruh }\end{array}$ & 54 & 91,5 & 5 & 8,5 & 59 & 100 & 0,426 & $\begin{array}{c}1,800 \\
(0,391- \\
8,292)\end{array}$ \\
\hline \multirow[t]{2}{*}{$\begin{array}{c}\text { Terpeng } \\
\text { aruh }\end{array}$} & 18 & 85,7 & 3 & 14,3 & 21 & 100 & & \\
\hline & 72 & 90 & 8 & 10 & 80 & 100 & & \\
\hline
\end{tabular}

Dari 80 anak remaja, di ketahui sebanyak

72 anak perilaku seksual tidak terpengaruh terhadap temen sebaya dimana 54 anak $91,5 \%$ berperilaku seksual baik dan 5 anak 8,5 berperilaku seksual tidak baik, sedangkan yang terpenngaruh terhadap teman sebaseksual baik dan 5 anak 8,5 berperilaku seksual tidak baik, sedangkan yang terpengaruh terhadap teman sebaya sebanyak 21 anak, dimana 18anak $85,7 \%$ berperilaku seksual baik dan 3 anak 14,3 berperilaku seksual tidak baik Berdasarkan uji hubungan dengan menggunakan Chi- Squere didapatkan nilai $\mathrm{P}=0,426 \quad(\mathrm{P}>0.05)$ dan nilai OR 1,800 (95\% CI:0,391-8,292 maka di simpulkan bahwa hubungan pengaruh temen sebaya tidak ada hubungan dengan perilaku seksual remaja..
Tabel 7

Distribusi Frekwensi Pengaruh Teman Sebaya Dengan Perilaku Seksual Remaja

\begin{tabular}{|c|c|c|c|c|c|c|c|c|}
\hline \multirow{3}{*}{$\begin{array}{c}\text { Media } \\
\text { masa }\end{array}$} & \multicolumn{6}{|c|}{ Tindakan perilaku seksual } & \multirow{3}{*}{$\begin{array}{l}\text { Nilai } \\
\mathrm{P}\end{array}$} & \multirow{3}{*}{$\begin{array}{l}\text { OR } \\
95 \% \mathrm{CI}\end{array}$} \\
\hline & \multicolumn{2}{|c|}{ Baik } & \multicolumn{2}{|c|}{ T.Baik } & \multicolumn{2}{|c|}{ Total } & & \\
\hline & $\mathrm{N}$ & $\%$ & $\mathrm{~N}$ & $\%$ & $\mathrm{~N}$ & $\%$ & & \\
\hline $\begin{array}{l}\text { Tidak } \\
\text { meng } \\
\text { gunak } \\
\text { an } \\
\text { media } \\
\text { porno }\end{array}$ & 54 & 94,7 & 3 & 5,3 & 57 & 100 & 0,040 & $\begin{array}{c}5,000 \\
(1,085- \\
23,034)\end{array}$ \\
\hline $\begin{array}{l}\text { meng } \\
\text { gunak } \\
\text { an } \\
\text { media } \\
\text { porno }\end{array}$ & 18 & 78,3 & 5 & 21,7 & 23 & 100 & & \\
\hline & 72 & 90 & 8 & 10 & 80 & 100 & & \\
\hline
\end{tabular}


Dari 80 anak remaja, di ketahui sebanyak 72 anak perilaku seksual tidak terpengaruh terhadap temen sebaya dimana 54 anak 91,5\% berperilaku seksual baik dan 5 anak 8,5 berperilaku seksual tidak baik, sedangkan yang terpenngaruh terhadap teman sebaya seksual baik dan 5 anak 8,5 berperilaku seksual tidak baik, sedangkan yang terpengaruh terhadap teman sebaya sebanyak 21 anak, dimana 18anak 85,7\% berperilaku seksual baik dan 3 anak 14,3 berperilaku seksual tidak baik Berdasarkan uji hubungan dengan menggunakan ChiSquere didapatkan nilai $\mathrm{P}=0,426(\mathrm{P}>0.05)$ dan nilai OR 1,800 (95\% CI:0,391-8,292 maka di simpulkan bahwa hubungan pengaruh temen sebaya tidak ada hubungan dengan perilaku seksual remaja..

\section{Pembahasan}

Pola asuh orangtua akan mempengaruhi perkembangan anak baik fisik maupun psikologis. Pada saat remaja perkembangan psikologis anak harus lebih diperhatikan oleh orangtua. Pada remaja waktu di luar rumah lebih banyak dibandingkan dengan waktu di dalam rumah sehingga pengaruh lingkungan akan sangat berpengaruh pada perkembangan psikologis remaja. Orangtua harus dapat melihat secara cermat perubahan perilaku yang dialami oleh anak remajanya, salah satunya adalah perilaku seksual yang dilakukan oleh remaja. Menurut Monks, dkk (1999) menyebutkan dua bentuk perkembangan remaja yaitu, memisahkan diri dari orangtua dan menuju kearah teman sebaya. Remaja berusaha melepaskan diri dari otoritas orangtua dengan maksud menemukan jati diri. Remaja lebih banyak berada di luar rumah dan berkumpul bersama teman sebayanya dengan membentuk kelompok dan mengeksperesikan segala potensi yang dimiliki. Kondisi ini membuat remaja sangat rentan terhadap pengaruh teman dalam hal minat, sikap penampilan dan perilaku. Perubahan yang paling menonjol adalah hubungan heteroseksual. Remaja akan memperlihatkan perubahan radikal dari tidak menyukai lawan jenis menjadi lebih menyukai. Remaja ingin diterima, diperhatikan dan dicintai oleh lawan jenis dan kelompoknya.

Pola asuh demokratis akan menghasilkan karakteristik anak anak yang mandiri, dapat mengontrol diri, mempunyai hubungan baik dengan teman, mampu menghadapi stress, mempunyai minat terhadap hal-hal baru, dan koperatif terhadap orang-orang lain.

Pola asuh otoriter akan menghasilkan karakteristik anak yang penakut, pendiam, tertutup, tidak 
berinisiatif, gemar menentang, suka melanggar norma, berkepribadian lemah, cemas dan menarik diri.

Hasil penelitian ini memperlihatkan bahwa anak-anak yang berada di sekolah yaitu SMAN 7 berjumlah 40 responden dan SMK 21 berjumlah 40 responden, dimana sampel di gabung menjadi satu sehingga berjumlah 80 responden

Dari hasil penelitian menunjukan bahwa dari dua kelompok remaja pola asuh permisif (pada tabel 1 dan 5) terlihatbahwapolaasuh orang otoritersebanyak 10 orang (12,5\%) danpolaasuh orang tua yang permisifsebanyak 70 orang $(87,5 \%)$.Hal ini sesuai dengan teori yang menyatakan bahwa polaasuh permisif akan menghasilkan karakteristik anak-anak yang impulsive, agresif, tidak patuh, manja, kurang mandiri, mau menang sendiri, kurang percaya diri, dan kurang matang secara sosial. .

Dari karakteristik-karakteristik tersebut di atas, kita dapat mawas diri, kita masuk dalam kategori pola asuh yang mana. Apabila kita memahami pola asuh yang mana yang cenderung kita terapkan, sadar atau tidak sadar, maka kita dapat segera merubahnya.

Kita juga bisa kita melihat, bahwa harga diri yang rendah terutama adalah disebabkan karena pola asuh orang tua yang penelantar. Banyak sekali para orangtua terutama para wanita karier yang suda mempunyai anak yang lebih cinta kepada pekerjaannya daripada kepada anaknya sendiri. Dia lebih banyak meluangkan waktu untuk mencari uang dan uang. Dia lupa kalau di rumah ada anak-anaknya yang membutuhkan kasih dan sayang nya. Pergi kerja disaat anaknya masih tertidur pulas, lalu pulang ketika anaknya sudah tertidur pulas lagi. Sehingga, anak-anak lebih mengenal pembantunya daripada sosok ibunya sendiri.

Dari hasil uji statistik, penelitian ini menunjukan bahwa pengaruh teman sebaya tidak ada hubungan yang signifikan dengan perilku seksual remaja. Berbeda teori menurut Monks, dkk (1999) menyebutkan dua bentuk perkembangan remaja yaitu, memisahkan diri dari orangtua dan menuju kearah teman sebaya. Remaja berusaha melepaskan diri dari otoritas orangtua dengan maksud menemukan jati diri.

Dari hasil uji statistik, hubungan antara media massa denganpengetahuan prilaku seksual remaja menunjukan hubungan yang signifikan. Sejalan dengan perkembangan sistem informasi banyak pihak-pihak tertentu yang sering menyalah gunakan media informasi demi keuntungan sendiri banyak anak -anak remaja. Media 
massa mempunyai peranan dominan dalam hal penyampaian informasi baik secara elektronik maupun tulisan sehingga apabila media massa yang tidak memperhatikan kode etik jurnalistik maka akan dapat menimbulkan pengaruh terhadap perilaku masyarakat khususnya perilaku pada remaja. Apabila dalam kontektual masalah seksual dapat juga menimbulkan suatu perubahan perilaku pada remaja yang sedang dalam massa transisi, bila menimbulkan pengaruh negatif maka akan berdampak penyimpangan-penyimpangan perilaku remaja tersebut misalnya dalam hal seksualitas hal ini sesuai dengan hasil penelitian Nasrul, Masudin, danLindanur (2011) diperoleh: terdapat pengaruh media massa terhadap pengetahuan dan tindakan siswa tentang seks di SMU/SMK di Kota PaludanKabupatenDonggala

MenurutYuke Herdian Siska dan Ediana Kusuma W Dalambuku "PertumbuhanPerkembanganEdisi II (1999), Teman sebaya dapat menimbulkan dampak negative dari suatu persahabatan atau pertemanan antara lain: 1. Remaja cenderung mengutamakan pilihan teman sebaya dari pada pilihannya sendiri dikarenakan keinginan untuk diakui oleh teman sebaya tersebut.2. Terjebak dalam pergaulan bebas ,hal ini biasanya disebabkan oleh perikaku teman sebaya dalam kelompok menjadi semacam acuan atau standar norma atau tingkah laku yang diharapkan dalam kelompok tersebut, misalnya: gaya berpacaran teman sebaya menjadi semacam model atau acuan yang digunakan seseorang remaja dalam berpacaran, jika teman-teman melakukan ciuman dalam berpacaran maka perilaku remaja lainpun akan demikian.

Hasil penelitian kami tidak sesuai dengan konsep teori tersebut diatas, kemungkinan disebabkan oleh karena factor polaasuh orang tua sebagian besar pola asuh otoriter sehingga remaja akan merasa takut untuk bertindak bebas.

\section{Simpulan}

Kesimpulan yang dapat diambil berdasarkan hasil penelitian terhadap siswa SMAN 7 Tangerang dan SMK Kesehatan 21 Tangerang. Berdasarkan hasil uji statistik Hasil penelitian didapatkan responden dengan pengetahuan perilaku seksual tidak baik sebanyak 8 orang (10\%) dari 80 responden, adanya hubungan yang bermakna antara media massa dengan pengetahuan perilaku seksual remaja dengan hasil uji staitistik $\mathrm{P}=0,040(\mathrm{P}<0,05)$ dan nilai OR 5,000 $(95 \%$ CI: 1M085-23,034). Sedangkan yang tidak mempunyai hubungan yang bermakna 
yaitu: pola asuh orang tua dan pengaruh teman sebaya.

\section{DaftarPustaka}

Athar Shahid, 2004, Bimbingan Seks bagi Kaum Muda Muslim, Pustaka Zahra, Jakarta.

Biro Pusat Statistik Kota Palembang, 2004, Palembang dalam Angka, BPS Palembang.

Dianawati Ajen, 2003, Pendidikan Seks untuk Remaja, Kawan Pustaka, Jakarta

Elis Elisabeth, 2002, Pembentukan Karakter Anak Butuh Keteladanan, Artikel kesehatan Reproduksi remaja diakses dari www. Suarakarya online.com.

Gusmian, Lilian, 2006, Remaja Bicara Seks, pacaran, Cinta dan Narkoba, Nuansa, Bandung.

Klipke, 2002, Tinjauan Umum Kesehatan Reproduksi Remaja, Kompas.

Monk, F.J, Knoers, A.M.P, Haditono, S.R, 1999. Psikologi Perkembangan, Pengantar dalam Berbagai Bagiannya. Gadjah Mada Uversity Press.Jogyakarta

Nugraha, 2004, Perilaku Remaja sudah diluar Batas Kewajaran, diakses dari www.pkbi.jogja
Notoatmojo, 2010, Metodologi Penelitian Kesehatan.Rinekacipta.Jakarta.

Nasrul, 2011.Dengan judul Penelitian "Pengaruh media massa terhadap pengetahuan dan tindakan siswa tentang seks di SMU/SMK di Kota Paludan Kabupaten Donggala”.

Tito, 2001, Potret Remaja dalam Data, Kompas

Yusuf, $\quad 2011$. PsikologiPerkembanganAnak\&Remaja .Remaja Rosdakarya.Bandung.

Yuke Herdian Siska dan Ediana Kusuma W, 1999. "Pertumbuhan Perkembangan Edisi II BKKBN.Jakarta 